\title{
Factor V Activity Measurement
}

National Cancer Institute

\section{Source}

National Cancer Institute. Factor V Activity Measurement. NCI Thesaurus. Code C103396.

The determination of the amount of the biological activity of factor $V$ in a sample. 